\title{
Pemodelan Matematika Bekam Pada Kanker Nasofaring Dan Kontribusinya Bagi Penanganan Kanker Nasofaring
}

\author{
Sugiyanto \\ Program Studi Matematika Fakultas Sains dan Teknologi, UIN Sunan Kalijaga, Jl. Marsda Adisucipto \\ No. 1 Yogyakarta, Indonesia \\ Korespondensi; Email: sugimath@yahoo.co.id
}

\begin{abstract}
Abstrak
Kanker / karsinoma nasofaring adalah kanker ganas di kepala dan leher. Hal ini terletak di nasofaring, di belakang hidung. Virus Ebstein Barr adalah salah satu pemicu karsinoma ini. Bekam adalah proses detoksifikasi racun dalam tubuh sehingga kekebalan meningkat. Cukup banyak perkataan Nabi Muhammad tentang bekam. Metode yang digunakan dalam penelitian ini adalah pemodelan matematika nasofang tingkat sel karsinoma. Ada dua kasus yang dimodelkan dalam kasus ini, kasus pertama kekebalan rendah tanpa bekam, dan kasus kedua kekebalan rendah dengan bekam tersebut. Kasus pertama kekebalan rendah tanpa bekam di sini terdiri dari tujuh sub-populasi yang terjadi, yaitu sel-sel normal, sel-sel lesi, sel rendah displastik, sel-sel yang terinfeksi, sel displastik tinggi, sel-sel karsinoma invasif dan virus. Sementara itu, dua kasus kekebalan rendah dengan bekam terdapat lima sub-populasi, yaitu sel-sel normal, sel-sel lesi, sel rendah displastik, sel-sel yang terinfeksi, dan virus.
\end{abstract}

Kata Kunci: Kanker / Karsinoma nasofaring; Pemodelan matematika; Virus Ebstein-Barr

\begin{abstract}
Cancer / Nasopharyngeal carcinoma is a cancer of the first malignancy in the head and neck. It is located in nasopharynx, behind the nose. Ebstein Barr virus is one of the triggers of this carcinoma. Cupping is a process of detoxification of toxins in the body so as immunity increases. Quite a lot of the sayings of the Prophet Muhammad about the cupping. The method used in this study mathematical modeling nasofang carcinoma cell level. There are two cases which are modeled in this case, the first case of low immunity without cupping, and second case low immunity with the cupping. The first case of low immunity without a cupping here are seven sub-populations that happened, ie normal cells, lesion cells, low dysplastic cells, the infected cells, high dysplastic cells, invasive carcinoma cells and viruses. Meanwhile, two cases of low immunity with the cupping there are five sub-populations, ie normal cells, lesion cells, low dysplastic cells, the infected cells, and viruses.
\end{abstract}

Keywords: Cancer / nasopharyngeal carcinoma; Mathematical modeling; Ebstein-Barr Virus

\section{Pendahuluan}

Tubuh terdiri dari triliunan sel hidup. Sel-sel normal tubuh tumbuh, membagi, dan mati secara teratur. Selama tahun-tahun awal kehidupan seseorang, sel normal membagi lebih cepat untuk memungkinkan orang untuk tumbuh. Setelah orang menjadi dewasa, kebanyakan sel-sel membagi hanya untuk menggantikan sel-sel yang usang atau mati untuk memperbaiki luka. [1]

Kanker dimulai ketika sel-sel di bagian tubuh tumbuh di luar kendali. Ada banyak jenis kanker, tetapi mereka semua mulai karena tidak adanya kontrol pertumbuhan sel abnormal. Sel-sel kanker dapat menyebar ke bagian tubuh lain dari tubuh melalui darah dan sistem getah bening. Sebagian besar kanker diberi nama untuk organ atau jenis sel tempat dimulainya, misalnya kanker yang dimulai dari nasofaring disebut kanker nasofaring. [1]

Perkataan "Al Hijamah" berasal dari istilah Bahasa Arab yang berarti "pelepasan darah kotor" dan bukan "Al Fashd" (pembuang darah). atau dalam bahasa Inggris disebut dengan "Cupping". dan dalam bahasa melayu dikenal dengan istilah "Bekam". Di Indonesia kita kenal denan istilah Kop atau Cantuk. 
Berbekam dapat menghilangkan rasa sakit pada bahu dan tenggorokan jika dilakukan pada bagian kuduk. Juga dapat menghilangkan sakit pada bagian kepala serperti muka, gigi, telinga dan hidung jika penyakit itu disebabkan oleh terjadinya penyumbatan pada darah atau rusaknya jaringan darah. Dari Anas RA bahwa Rosulullah bersabda: Sesungguhnya jika ada sesuatu yang bisa menyembuhkan maka itu adalah bekam dan qustul bahri HR. Muslim. [5]

\section{Pembahasan}

Hingga saat ini riset-riset pemodelan matematika terkait kanker nasofaring adalah pemodelan statistik, yaitu meninjau kanker nasofaring berdasarkan umur, jenis kelamin dan tentang glucose transport. Kemudian penelitian tersebut dikaitkan dengan strategi pemberian vaksin/imunisasi sebagai upaya preventif penyebaran kanker nasofaring. Belum ada penelitian pemodelan kanker nasofaring dengan bekam/hijamah dalam lingkup perkembangan sel nasofaring dalam tubuh penderita, dari sel nasofaring normal hingga akhirnya menjadi sel kanker. Padahal penelitian mengenai hal tersebut akan sangat berguna bagi dunia medis sebagai pertimbangan dalam memberikan treatment yang tepat bagi penderita kanker nasofaring sehingga angka kematian akibat kanker nasofaring dapat ditekan. [3]

Sel yang terinfeksi EBV mengekspresikan beberapa antigen virus yang spesifik untuk setiap periode infeksi. Infeksi laten EBV ditandai oleh ekspresi protein Epstein-Barr Virus Nuclear Antigen-1 (EBNA-1) dan EBNA-2, Membrane Protein Laten (LMP), dan Epstein Barr virus Encoded small RNAs (EBER). Protein-protein ini dapat mengadakan interaksi atau mempunyai homologi dengan berbagai protein tubuh seperti protein antiapoptosis, sitokin dan transduksi sinyal. Protein virus berperan dalam mempertahankan genom EBV pada sel B. Terdeteksi pada semua periode infeksi laten ([4] dan [2]). Gambar 1 berikut merupakan proses perkembangan sel normal menjadi sel infansif karinoma.

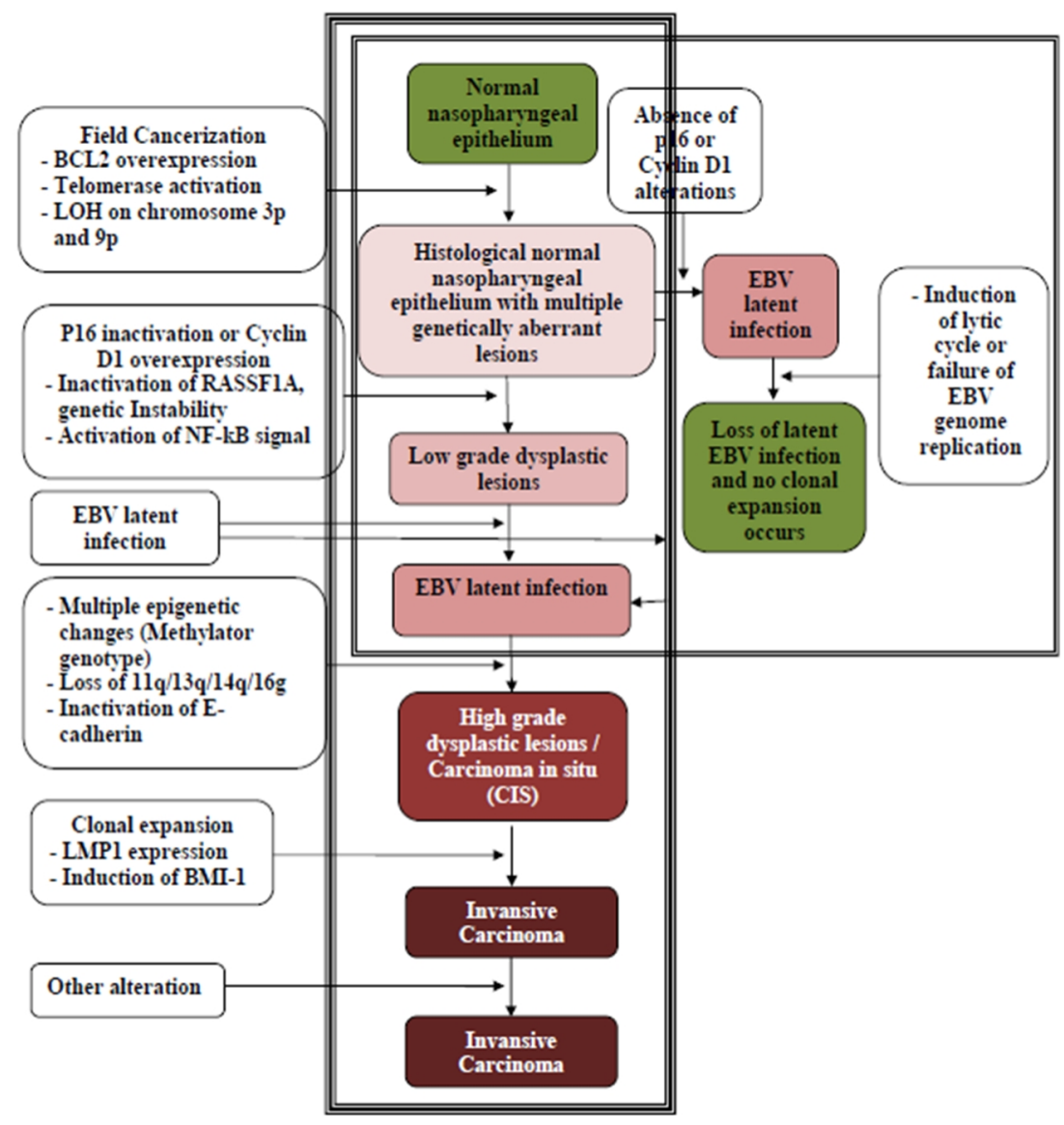

Keterangan: $\square$ Sistem imunitas rendah dengan bekam, 回 Sistem imunitas rendah tanpa bekam

Gambar 1 Model tumorigenesis untuk keterkaitan antara EBV dan karsinoma nasofaring. 


\section{Pemodelan Matematika Karsinoma Nasofaring Dengan Pembekaman}

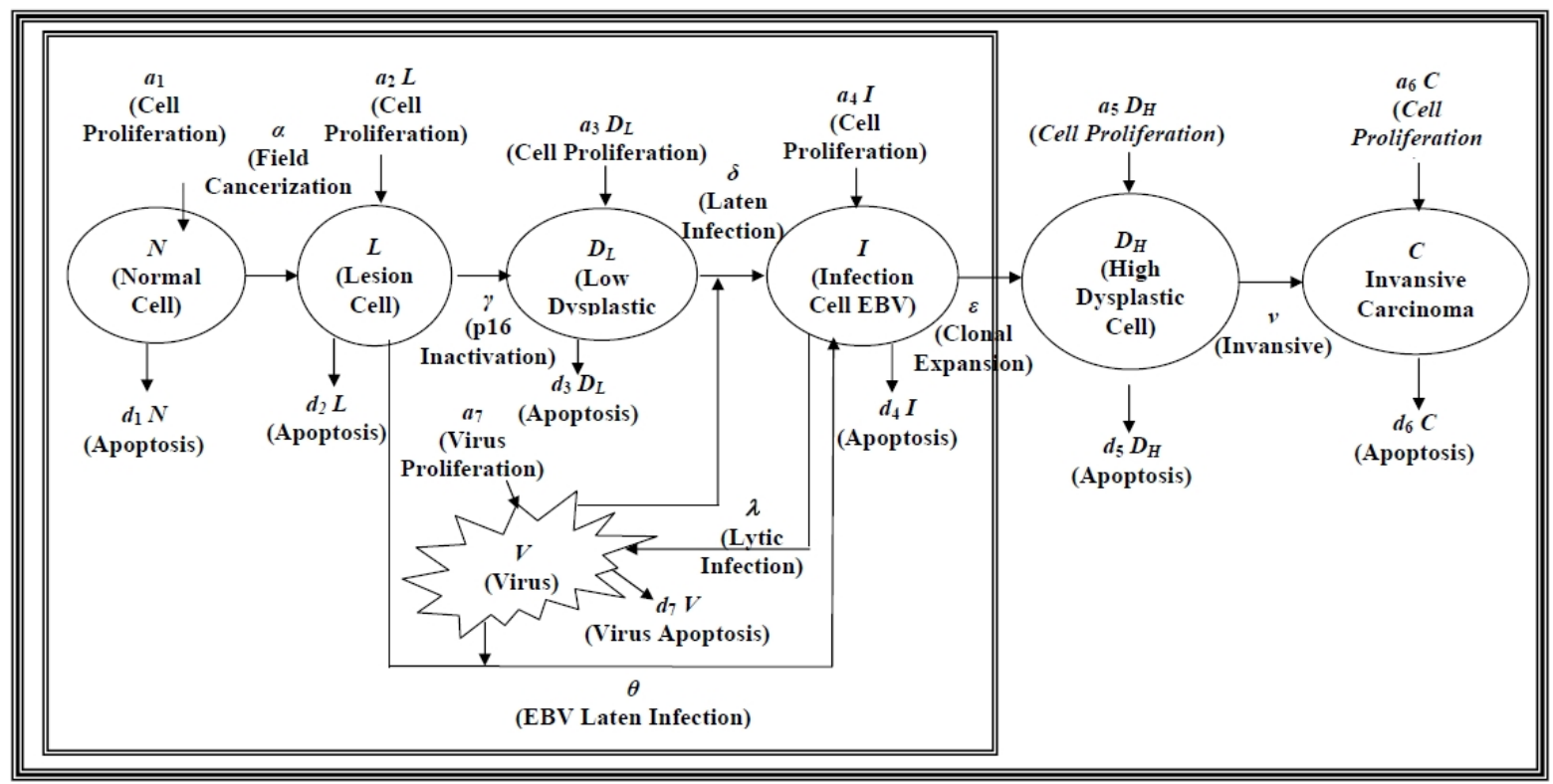

Keterangan: $\square$ Sistem imunitas rendah dengan bekam, 回 Sistem imunitas rendah tanpa bekam

Gambar 2 Model sistem yang terbentuk pada karsinoma nasofaring.

Seluruh sel epitelium nasofaring dianggap memiliki reseptor yang sama sehingga laten EBV bisa menjadi aktif EBV dan menginfeksi sebarang sel nasofaring, tanpa preferensi. Dengan kata lain, diasumsikan random kontak antara sel epitelium nasofaring dengan virus EBV. Populasi sel nasofaring terbagi menjadi enam sub populasi, sel normal, sel luka, sel diploplastik rendah, sel terinfeksi EBV, sel diploplastik tinggi, sel invansi karsinoma. Sel normal $(M)$ mengalami luka $(L)$, bisa karena makanan berpengawet atau tembakau. Sel nasofaring yang luka dapat berlanjut ke sel diploplastik rendah $\left(D_{L}\right)$, bisa karena lemah sistem imun, sehingga tidak terjadi perbaikan gen atau apoptosis. Epstein-Barr Virus ( $V$ ) menginfeksi sel luka atau diploplastik rendah, sehingga sel menjadi terinfeksi. Sel nasofaring yang teinfeksi (/) yang tidak terjadi apoptosis dapat berlanjut menjadi sel diploplastik tinggi $\left(D_{H}\right)$. Sel diploplastik tinggi dapat berlanjut menjadi sel invansi karsinoma ( $C$ ). Sel invansi karsinoma tidak dapat sembuh, hingga berakhir dengan kematian penderita. Sistem persamaan matematikanya adalah sebagai berikut.

$$
\begin{aligned}
\frac{d}{d} & =a_{1}-\alpha-d_{1} N \\
\frac{d}{d} & =a_{2} L+\alpha-\beta-\theta-\gamma-d_{2} L \\
\frac{d D_{L}}{d} & =a_{3} D_{L}+\gamma-\delta D_{L} V-d_{3} D_{L} \\
\frac{d}{d} & =a_{4} I+\delta D_{L} V+\theta-\varepsilon-d_{4} I \\
\frac{d D_{H}}{d} & =a_{5} D_{H}+\varepsilon-v D_{H}-d_{5} D_{H} \\
\frac{d}{d} & =a_{6} C+v D_{H}-d_{6} C \\
\frac{d}{d} & =a_{7}+\lambda a_{4} I-d_{7} V
\end{aligned}
$$


Dimana

$N(t)=$ Kepadatan sel epitelium di nasofaring

$L(t)=$ Kepadatan sel epitelium lesion

$D_{L}(t)=$ Kepadatan sel displastik rendah (mengindikasikan sel sakit abnormal)

$I(t) \quad=$ Kepadatan sel terinfeksi EBV latent

$D_{H}(t)=$ Kepadatan sel lesion dysplastik tinggi

$C(t)=$ Kepadatan sel invansif karsinoma

$V(t)=$ Kepadatan sel EBV lytic

$\alpha=$ Laju medan kanker

$\gamma \quad=$ Laju tidak aktifnya p16

$\theta \quad=$ Laju infeksi EBV latent dari sel lesion ke sel terinfeksi

$\delta \quad=$ Laju EBV infeksi EBV latent dari sel displastik rendah ke sel terinfeksi

$\varepsilon \quad=$ Laju ekspansi klonal (bentuk medis untuk model bagaimana sistem imun merespon infeksi)

$v \quad=$ Laju invansif

$\lambda \quad=$ Laju infeksi lityc

$a_{1} \quad=$ Proliferasi sel normal epitel di nasofaring

$a_{2} \quad=$ Laju proliferasi sel epitel lesion

$a_{3} \quad=$ Laju proliferasi sel dysplastik rendah

$a_{4} \quad=$ Laju proliferasi sel infeksi

$a_{5} \quad=$ Laju proliferasi sel displastik tinggi

$a_{6} \quad=$ Laju proliferasi invansif karsinoma

$a_{7} \quad=$ Laju proliferasi EBV lytic

$d_{1} \quad=$ Laju apoptosis sel normal

$d_{2} \quad=$ Laju apoptosis sel epitel lesion

$d_{3} \quad=$ Laju apoptosis sel displastik rendah

$d_{4} \quad=$ Laju apoptosis sel infeksi

$d_{5} \quad=$ Laju apoptosis dysplastik tinggi

$d_{6} \quad=$ Laju apoptosis invansif karsinoma

$d_{7} \quad=$ Laju apotosis EBV lytic

\section{Simulasi Model}

Parameter yang dipilih diberikan dalam bentuk tabel berikut ini.

Kasus I = Sistem imunitas rendah tanpa bekam.

Kasus $\|$ = Sistem imunitas rendah dengan bekam.

Tabel 1 Nilai-nilai estimasi parameter model karsinoma nasofaring untuk kasus sistem imunitas rendah tanpa bekam.

\begin{tabular}{ccccccccc}
\hline No & Parameter & Nilai & No & Parameter & Nilai & No & Parameter & Nilai \\
\hline 1 & $a_{1}$ & 100 & 8 & $d_{1}$ & 1 & 15 & $\alpha$ & 5 \\
2 & $a_{2}$ & 2 & 9 & $d_{2}$ & 2 & 16 & $\gamma$ & 6 \\
3 & $a_{3}$ & 1 & 10 & $d_{3}$ & 2 & 17 & $\theta$ & 1 \\
4 & $a_{4}$ & 1 & 11 & $d_{4}$ & 2 & 18 & $\delta$ & 0.5 \\
5 & $a_{5}$ & 2 & 12 & $d_{5}$ & 3 & 19 & $\varepsilon$ & 1 \\
6 & $a_{6}$ & 2.5 & 13 & $d_{6}$ & 3 & 20 & $v$ & 2 \\
7 & $a_{7}$ & 2 & 14 & $d_{7}$ & 2 & 21 & $\lambda$ & 1 \\
\hline
\end{tabular}




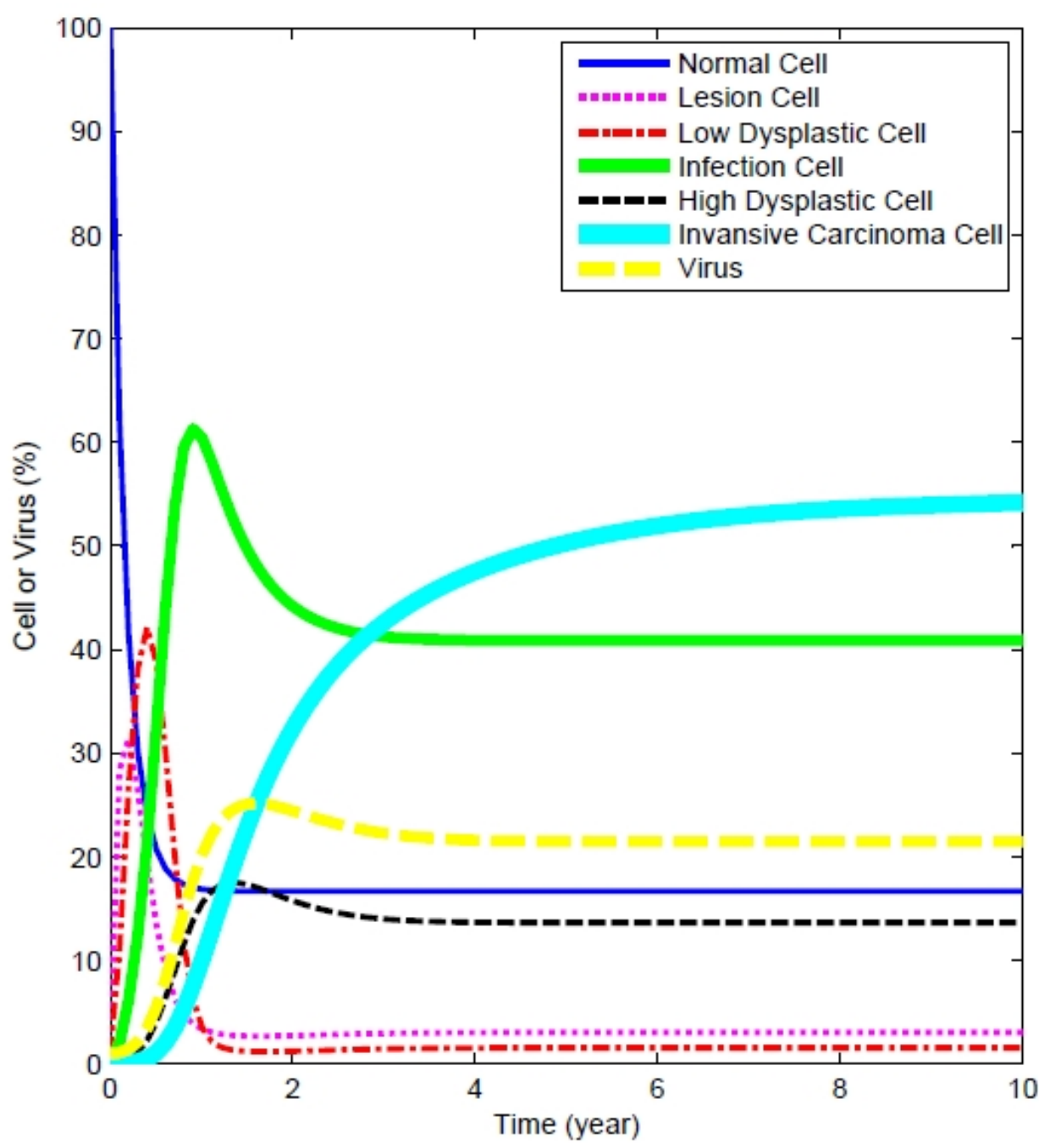

Gambar 3 Proses perkembangan sel nasofaring dengan kasus imunitas rendah tanpa bekam.

Pada Gambar 3 merupakan proses perkembangan sel di epitel nasofaring dengan kasus imunitas rendah tanpa bekam/hijamah. Pada kasus I ini, normal cel/ terjadi penurunan sangat cepat pada tahuntahun awal seiring dengan kenaikan lesion cell yang sangat cepat. Ketika p16 tidak aktif, maka lesion cell menjadi low dysplastic cell. Adanya lytic EBV menyebabkan sel abnormal low dysplastic cell dengan mudah dapat diinfeksi oleh lytic EBV dan menjadikan infection cell. Karena terjadi clonal expansion maka infection cell menjadi high dysplastic cell. Lytic EBV terjadi kenaikan signifikan. Karena high dysplastic cell tinggi dan sistem imun masih rendah, maka invansive carcinoma tejadi.

Tabel 2 Nilai-nilai estimasi parameter model karsinoma nasofaring untuk kasus sistem imunitas rendah dengan bekam.

\begin{tabular}{cccccc}
\hline No & Parameter & Value & No & Parameter & Value \\
\hline 1 & $a_{1}$ & 100 & 9 & $d_{4}$ & 2 \\
2 & $a_{2}$ & 1 & 10 & $d_{7}$ & 1 \\
3 & $a_{3}$ & 1 & 10 & $\alpha$ & 0.1 \\
4 & $a_{4}$ & 1 & 11 & $\theta$ & 1 \\
5 & $a_{7}$ & 1 & 12 & $\gamma$ & 1 \\
6 & $d_{1}$ & 1 & 13 & $\delta$ & 0.6 \\
7 & $d_{2}$ & 2 & 14 & $\lambda$ & 0.1 \\
8 & $d_{3}$ & 2 & & & \\
\hline
\end{tabular}




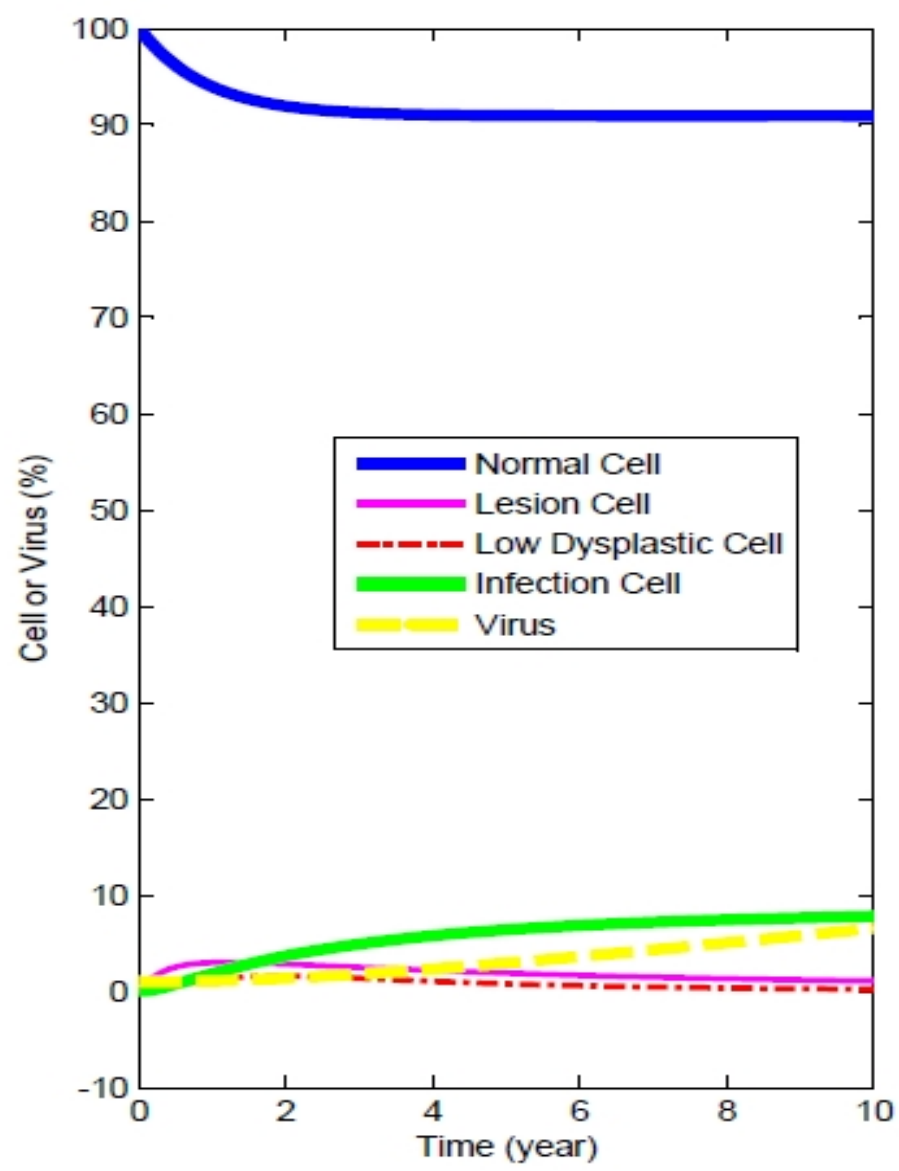

Gambar 4 Proses perkembangan sel nasofaring dengan kasus imunitas rendah dengan bekam.

Pada Gambar 4 merupakan simulasi perkembngan perkembangan sel nasofaring dengan kasus imunitas rendah dengan bekam. Pada kasus II ini, sel normal terjadi penurunan sangat cepat pada tahun-tahun awal seiring dengan kenaikan sel lesion yang sangat cepat. Ketika p16 tidak aktif, maka sel lesion menjadi sel displastik rendah. Adanya EBV lytic menyebabkan sel abnormal sel displastik rendah dengan mudah dapat diinfeksi oleh EBV lytic dan menjadikan sel terinfeksi. Sistem imun tinggi karena bekam yang rutin, maka sel displastik tinggi dan sel invansif karsinoma tidak tejadi.

\section{Kesimpulan}

Adanya dua kasus, kasus pertama imunitas rendah tanpa dibekam dan imunitas rendah tanpa dibekam. Untuk kasus pertama terinfeksi EBV dan sel infansif karsinoma berkembang sangat pesat. Ini yang perlu menjadi perhatian khusus, agar kanker nasofaring tidak berkembang. Pada kasus pertama ini merupakan kasus yang tidak aman dari karsinoma nasofaring. Untuk kasus yang kedua imunitas rendah tanpa dibekam dan imunitas rendah dengan dibekam. Untuk kasus kedua ini perkembangan sel displastik tinggi masing dapat diantisipasi oleh sistem imun. Sehingga kasus kedua ini tidak menyebabkan karsinoma nasofaring karena detoksifikasi bekam

\section{Referensi}

[1] American Cancer Society, 2015, Nasopharyngeal Cancer.

[2] Cohen JL, 2000, Eipstein-Barr Virus infection. N Engl J Med.

[3] Sugiyanto, et. al., 2014, Mathematical modeling of nasopharynx carcinoma on cell level, AIP Publishing LLC.

[4] Thompson MP et al., 2004, Eipstein Barr virus and cancer. Clin Cancer Res.

[5] http://www.univer-science.com/2014/08/manfaat-bekam-jenis-bekam-dan-efek.html 